\title{
"Japan Prize Week" 日本国際賞週間行事の紹介
}

4月23日（木）の2015年（第31回）Japan Prize授賞式・祝宴を核とし、その週をJapan Prize Week と称し、各種行事を催しました。

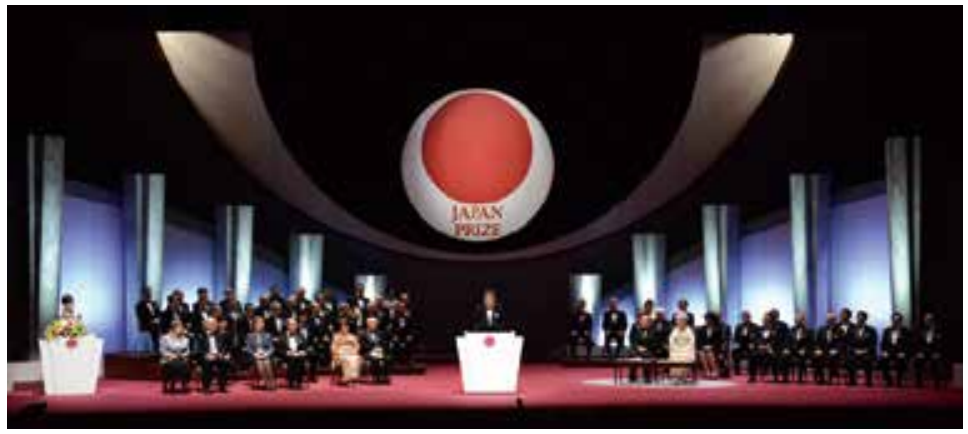

授賞式

2015年（第31 回）Japan Prize授賞式は天皇皇后両陛下ご臨席の下、大島理森衆議院議長、山崎正昭参 議院議長、寺田逸郎最高裁判所長官、下村博文文部科学大臣、太田昭宏国土交通大臣、山口俊一内閣府 特命担当大臣をはじめ、学界、財界の代表者ら約 1,000名が出席して開催されました。「日本国際賞式典序曲一 Overture Japan」の演奏で幕を開けた授賞式では、受賞者の家族、友人が客席で見守る中、国際科学技術 財団吉川弘之会長から各受賞者に賞状と賞牌、ご夫人方に花束が贈られました。タキシードに身を包んだ受賞者 は、それぞれ壇上で受賞の喜びを語りました。式典に引き続き催された記念演奏会では、受賞者のリクエストで、 モーツアルト作曲交響曲第38番ニ長調「プラハ」K.504より「フイナーレ」スメタナ作曲交響詩「モルダウ」、ブ ラームス作曲交響曲第 4 番ホ短調作品 98 より第 3 楽章」などが、東京藝術大学シンフォニー・オーケストラによ り演奏されました。また、式典序曲「Overture Japan」は国際的作曲家三木稔氏が書き下ろした作品で、1990 年の第6 回授賞式典で初演されて以来、毎年演奏されています。

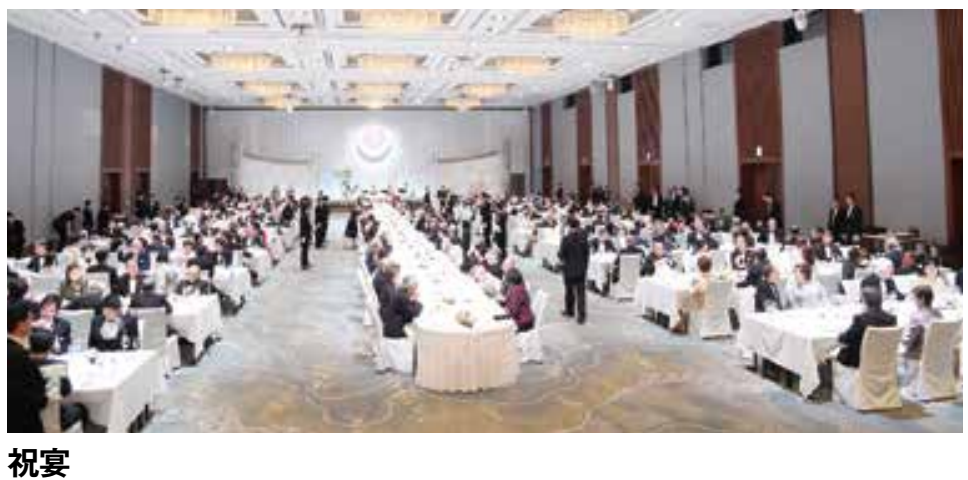

授賞式後、都内のホテルに場所を移して祝宴が催されました。天皇陛下による乾杯のご発声で、300名余りの 出席者が杯をあげて宴が始まりました。弦楽四重奏とハープが優雅な音楽を奏でる中で、天皇皇后両陛下は両 脇の受賞者夫妻と歓談。約 1 時間半にわたった宴は山崎参議院議長からのご祝辞を頂き、受賞者の謝辞で締め くくられまた。

高橋博士は総合的な流域管理の概念を得るに至つた経緯を述べた上で、自身の自然観を育てた多様な日本の 河川群とその河川を育てた日本の国土への感謝を述べました。「医薬、薬学」分野で共同受賞となったつリードマン、 フイッシャー両博士は互いに敬意を表しつつ、病気を最も基本的レベルで攻撃して決定的な治療をもたらす遺伝子 治療の革新性を述べるとともに今後の可能性に言及し、また、研究を支えた患者、その家族、科学者仲間に謝 意を表しました。 


\section{5年（第31回）Japan Prize 受賞記念講演会}

授賞式に先立つ4月21日（火）午後6時 30 分から東京・本郷の東京大学伊藤国際学術研究センター「伊藤 謝恩ホール」で記念講演会が行われました。

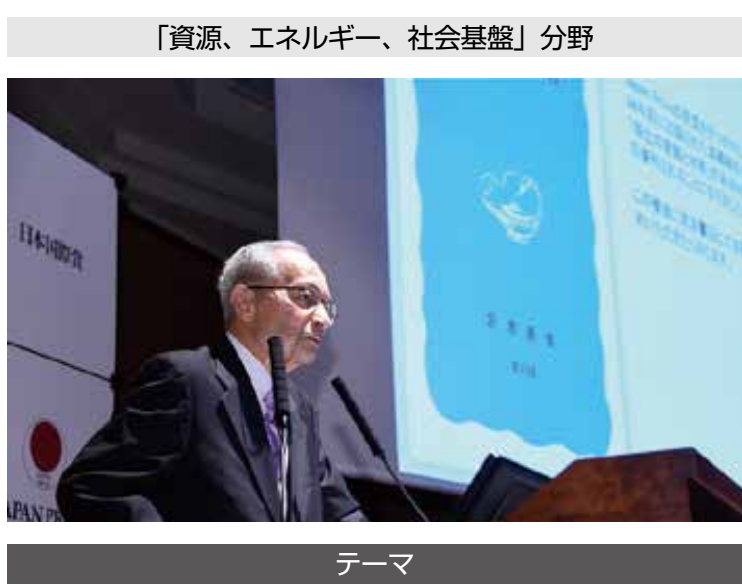

日本人と河川技術の歴史 (高橋博士)

カスリーン台風（1947年)、伊勢湾台風（1959年）など甚 大な水災害が相次いで日本を襲った時代に研究者としての道 を歩み始めた高橋裕博士は、明治以降の近代化と治水事業 が水災害にどのような影響を及ぼしてきたかを科学的に分析、 1971年の著書『国土の変貌と水害』で自説を発表しました。 そこには現在の総合治水の基礎となる考え方が明解に示され ていました。

今回、高橋博士が記念講演「日本人と河川技術の歴史」 で語ったのは、治水技術の原点は、人類が古から挑戦してき た「水災害との戦い」のなかにあるということです。

例えば、日本で最初の本格的治水事業として知られる、武 田信玄が築いた信玄堤。紀元前 3 世紀の中国に築かれた都 江堰を模範とし、富士川の氾濫による甲府盆地の洪水被害を 防ぐために築かれました。これは現代の治水の理念に通じま す。高橋博士は「近くの高岩という場所に上ると信玄堤を見 下ろせる。ここで武田信玄は、川を見て自然な汇濫は受け入 れ、守るべきところはしっかり守るという戦略を持っていたのだ と思う」と話します。また、高橋博士は日本の河川技術の発 展を主導した指導者たちとその業績を具体例を挙げて紹介し ました。彼らはそれぞれに強い信念と公共事業は人類のため という高い倫理をもち、技術発展に向けて議論を重ねました。 「先人の真摰な論争が今日の国土を守る礎になった」と博士 は熱く語りました。

最後に、若い研究者に対し、実際に現場に足を運び五感 を使って河川を観察して欲しいと期待を述べました。

「医学、薬学」分野

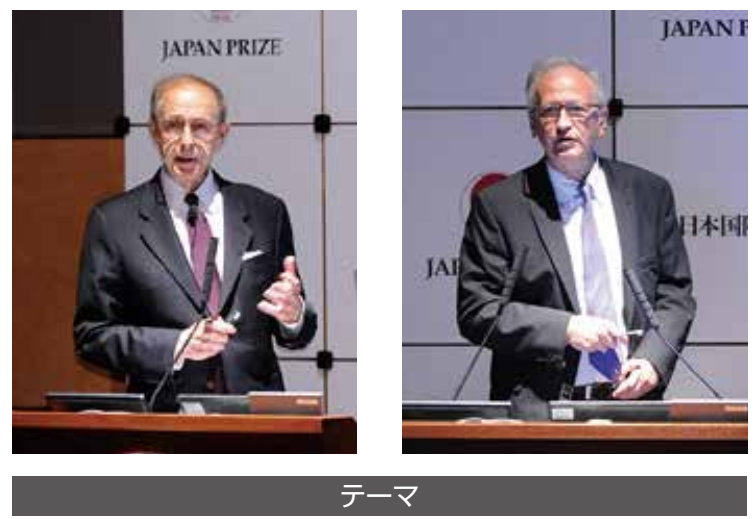

遺伝子治療45年の旅－理念誕生から最新医療まで (フリードマン博士)

遺伝子治療 : 免疫不全症から始まり多梯な疾病の治療へ (フイッシャー博士)

遺伝子治療とは、患者の細胞に人工的に遺伝子を導入す ることで病気を治療する手法です。

セオドア・フリードマン博士は、1972年に遺伝子治療の概念 と研究の進め方に関する重要な論文を発表。遺伝子治療の もたらす道徳的側面にも光を当て、遺伝子治療の社会的イン パクトについても常にオピニオンリーダーでした。フリードマン博 士は、講演「遺伝子治療 45 年の旅一理念誕生から最新医 療まで」で、遺伝子治療に取り組むきっかけとなったレッシュ・ ナイハン症候群について説明しました。博士は「多くの細胞 に効率よく、しかも安全に遺伝子を導入できれば臨床応用が 可能だ」と考え、さまざまな技術を評価し体系立てました。そ の内容をまとめたのが1972年の論文「Gene Therapy for Human Genetic Disease」です。この論文は多くの研究者 に影響を与えました。

最初に画期的な臨床成果を上げたのはアラン・フイツシャー 博士の研究グループでした。フイッシャー博士は、1999年にX 連鎖重症複合免疫不全症の患者の遺伝子治療を実施し、現 実の医療となりえることを初めて実証しました。博士は講演「遺 伝子治療: 免疫不全症から始まり多様な疾病の治療へ」で、 先天性免疫不全症への取り組みの重要性を説きました。

いま遺伝子治療は急速に広がろうとしています。フリードマ ン博士は、がんや網膜疾患の治療、遺伝子治療を応用した HIVワクチンなどを紹介。フイッシャー博士は「目的遺伝子を 挿入するだけではなく、患者の遺伝子そのものを治療する高 度な遺伝子治療」の将来像を語りました。 

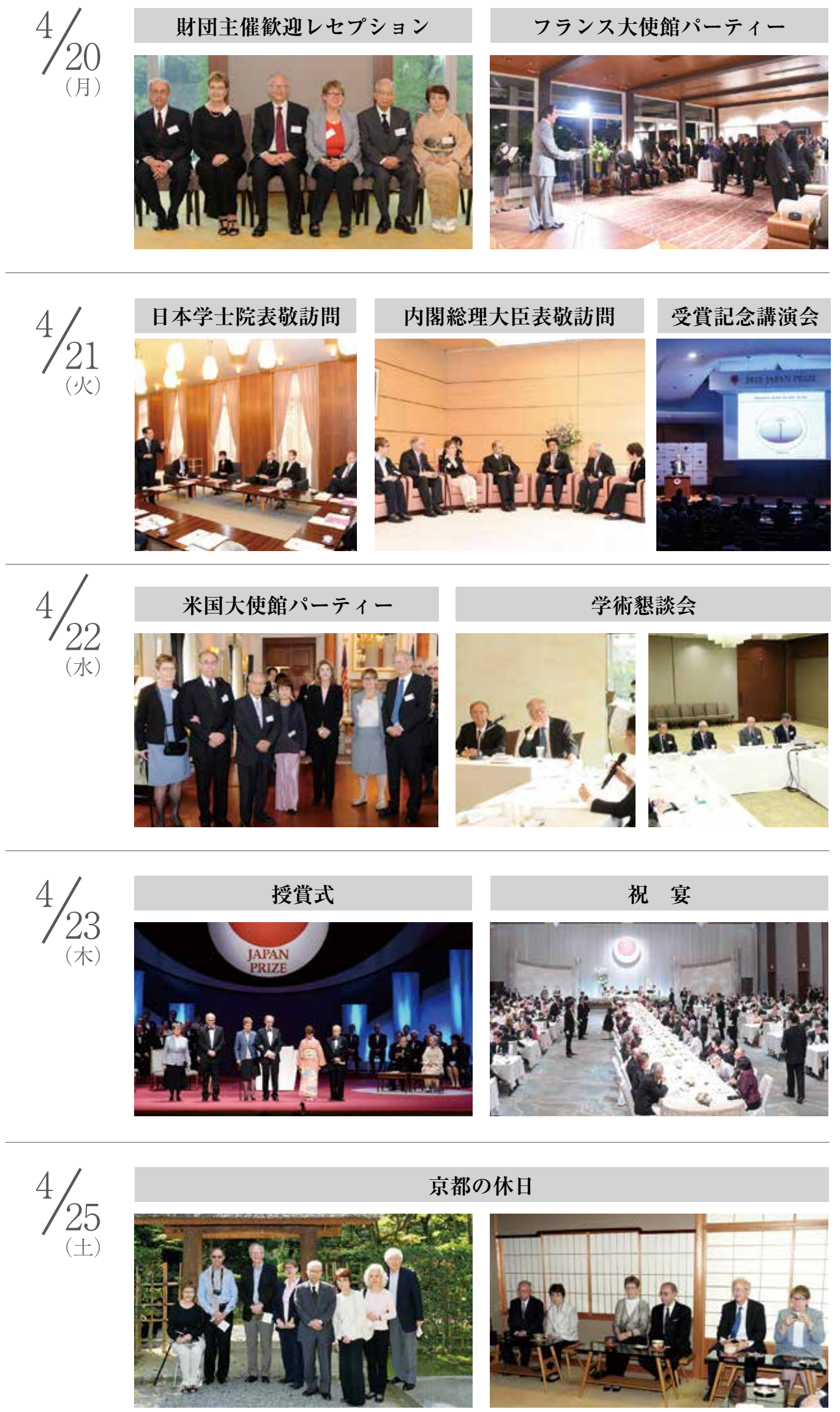

| 桂離宮にて

京都の休日

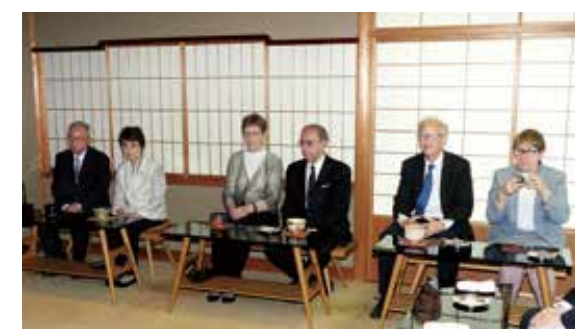

|松下 真々庵にて 
公益財団法人国際科学技術財団は 1982 年に設立され、Japan Prize 国際科学技術財団とは による顕彰事業のほかに、若手科学者の育成のための研究助成事業 や、一般の方々を対象とした「やさしい科学技術セミナー」の開催な ど、科学と技術の更なる発展に貢献するための活動を行っています。

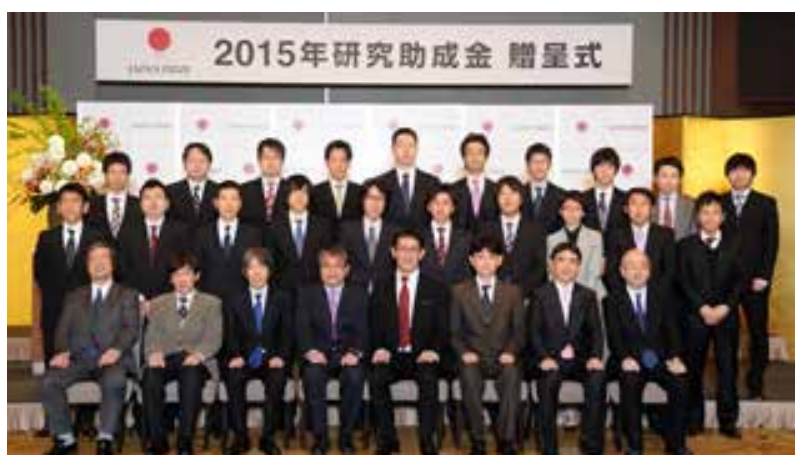

\section{研究助成事業}

Japan Prize の授賞対象分野と同じ分野で研究 する 35 歳以下の若手科学者を対象に、独創的で発 展性のある研究に対し、2006 年以降、これまでに 161 名に助成を行っています。将来を嘱望される 若手科学者の研究活動を支援・奨励することによ り、科学技術の更なる進歩とともに、それによっ て人類の平和と繁栄がもたらされることを期待し ています。

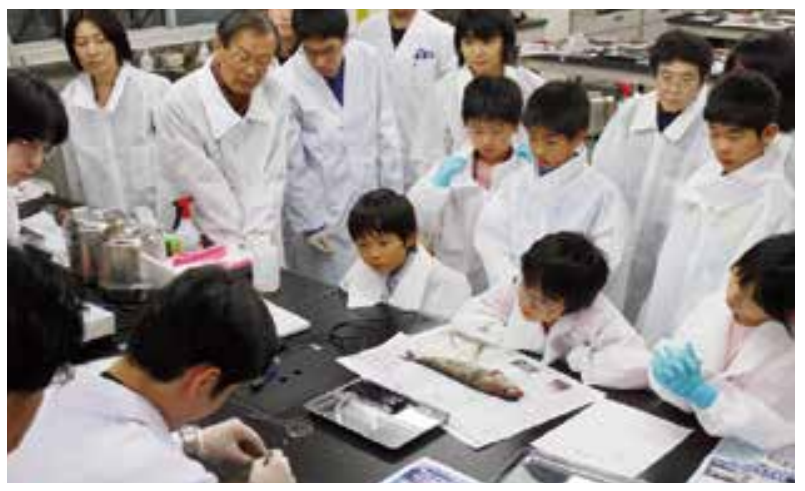

\section{「やさしい科学技術セミナー」の開催}

私たちの生活に関わりのある、様々な分野の 科学技術について、研究助成に選ばれた研究者を 講師に迎え、やさしく解説していただきます。講 義だけでなく実験や研究室の見学などを交えるこ とで、より理解しやすく科学への興味をかきたて る内容にしています。次世代を担う中学生や高校 生を中心に年 10 回程度全国各地で開催しており、 1989 年以降、これまでに 252 回開催しています。

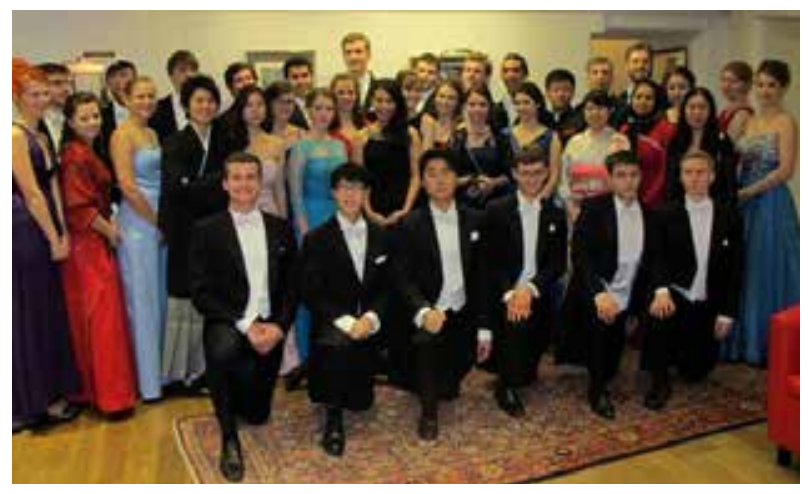

「ストックホルム国際青年科学セミナー」 への学生派遣

ノーベル財団の協力でスウェーデン青年科学者 連盟が毎年ノーベル賞週間に合わせてストックホル ムで開催する「ストックホルム国際青年科学セミ ナー (SIYSS)」に毎年 2 名の学生 (大学生・大学 院生）を派遣しています。SIYSSには世界各国から 派遣された若手科学者が集い、ノーベル賞授賞式な ど諸行事に参加したり、自身の研究発表を行います。 SIYSS への派遣は、比類ない国際交流の機会を提供 するだけでなく、若手科学者の科学に対するモラル の向上や熱意の高揚にも役立っています。1987 年以 降、これまでに 54 名の学生を派遣しています。 